\title{
Computerization of primary health care: the manager as a change agent
}

\author{
Informatização da atenção primária à saúde: o gestor como agente de mudança \\ Informatización de la atención primaria de salud: el gestor como agente de cambio
}

Tarcísio Laerte Gontijo'
ORCID: 0000-0001-7845-3825

Paola Karol Martins Lima'

ORCID: 0000-0001-8792-3315

Eliete Albano de Azevedo Guimarães' ORCID: 0000-0001-9236-8643

Valéria Conceição de Oliveira' ORCID: 0000-0003-2606-9754

Humberto Ferreira de Oliveira Quites' ORCID: 0000-0002-7299-5217

Vinícius Silva Belo' ORCID: 0000-0003-0183-1175

Ricardo Bezerra Cavancante" ORCID: 0000-0001-5381-4815

'Universidade Federal de São João Del Rei. Divinópolis, Minas Gerais, Brazil.

"Universidade Federal de Juiz de Fora. Juiz de Fora, Minas Gerais, Brazil.

How to cite this article: Gontijo TL, Lima PKM, Guimarães EAA, Oliveira VC, Quites HFO, Belo VS, et al. Computerization of primary health care: the manager as a change.

Rev Bras Enferm. 2021;74(2):e20180855. doi: http://dx.doi.org/10.1590/0034-7167-2018-0855

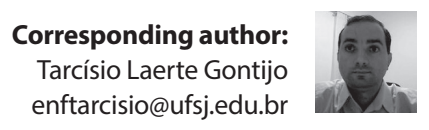

EDITOR IN CHIEF: Antonio José de Almeida Filho ASSOCIATE EDITOR: Andrea Bernardes

Submission: 10-09-2019 Approval: 02-19-2020

\begin{abstract}
Objective: To analyze factors associated with the implementation of software systems of the e-SUS Primary Care strategy in municipalities of Minas Gerais. Methods: This is a crosssectional study conducted with municipal managers of the e-SUS Primary Care strategy. A sample of cities stratified according to population size was selected. Descriptive, bivariate, and multivariate analyzes were performed to identify factors associated with the implementation of the systems. Results: In $49.1 \%$ (95\%Cl: $39.5-58.8$ ) of the municipalities investigated, some of the e-SUS Primary Care systems were implemented. Time working as a strategy manager (OR: 3.03) and training for Primary Care professionals in the municipality (OR: 2.28) were associated with the implementation of the systems. Conclusion: The presence of a trained manager leading the implementation process impacted the implementation of the e-SUS AB strategy software systems in the municipalities of Minas Gerais. It is also essential to highlight the need to improve the technological infrastructure for the computerization of Primary Care. Descriptors: Primary Health Care; Health Information Systems; Medical Informatics; Information Management; Cross Sectional Studies.
\end{abstract}

\section{RESUMO}

Objetivo: Analisar fatores associados com a implementação dos sistemas de software da estratégia e-SUS Atenção Básica em municípios de Minas Gerais. Métodos: Trata-se de estudo transversal realizado com gestores municipais da estratégia e-SUS Atenção Básica. Selecionouse amostra de municípios estratificados segundo porte populacional. Realizaram-se análises descritivas, bivariadas e multivariadas para identificar fatores associados a implementação dos sistemas. Resultados: Em 49,1\% (IC95\%: 39,5-58,8) dos municípios investigados houve implementação de algum dos sistemas da estratégia e-SUS Atenção Básica. O tempo de atuação como gestor da estratégia (OR: 3,03) e a realização de capacitações para os profissionais da Atenção Básica no município (OR: 2,28) estiveram associados a implementação dos sistemas. Conclusão: A presença de gestor capacitado a frente do processo de implantação impactou na implementação dos sistemas de software da estratégia e-SUS AB nos municípios mineiros. É importante destacar ainda a necessidade de melhoria na infraestrutura tecnológica para informatização da Atenção Básica.

Descritores: Atenção Primária à Saúde; Sistemas de Informação em Saúde; Informática Médica; Gestão da Informação; Estudos Transversais.

\section{RESUMEN}

Objetivo: Analizar factores asociados a la implementación de sistemas de software de la estrategia e-SUS Atención Básica en municipios de Minas Gerais. Métodos: Estudio transversal realizado con gestores municipales de estrategia e-SUS Atención Básica. Muestra seleccionada por estratificación de municipios según porte poblacional. Fueron realizados análisis descriptivos, bivariados y multivariados para identificar factores asociados a implementación de sistemas. Resultados: En el 49,1\% (IC95\%; 39,5-58,8) de los municipios estudiados hubo implementación de algún sistema de estrategia e-SUS Atención Básica. El tiempo de actuación como gestor (OR: 3,03$)$ y las capacitaciones recibidas por los profesionales de Atención Básica del municipio (OR:2,28) estuvieron asociadas con la implementación de sistemas. Conclusión: El gestor capacitado al frente del proceso de implantación impactó en la implantación de los sistemas de la estrategia de e-SUS AB en los municipios de Minas Gerais. Corresponde destacar la necesidad de mejorar la infraestructura tecnológica para informatizar la Atención Básica.

Descriptores: Atención Primaria de Salud; Sistemas de Información en Salud; Informática Médica; Gestión de la Información; Estudios Transversales. 


\section{INTRODUCTION}

The Brazilian Ministry of Health (MS) has been acting, since 2013, in the computerization of Primary Care (AB) through the implementation of the Health Information System for Primary Care (SISAB) ${ }^{(1)}$. This has been accomplished through the e-SUS Primary Care strategy (e-SUS AB), of the Department of Primary Care of the Brazilian Ministry of Health. This strategy consists of a set of actions aimed at improving the management and coordination of care based on the computerization of Basic Health Units (UBS) ${ }^{(1)}$. Also, the MS recently begun a program to support the computerization and qualification of Primary Health Care data (Informatiza APS) that guarantees financial support to municipalities and the Federal District ${ }^{(2)}$.

These strategies intend to restructure the Primary Care (AB) information at the national level, promoting individualized data and a complete record, improving the quality of information management, and, consequently, the care provided to the population at this level of complexity ${ }^{(1-2)}$. This proposal also impacts the organization of work, the collection, processing, and validation of health information and the care management ${ }^{(3-4)}$, requiring changes in the ideas and practices of professionals and users of the service ${ }^{(3)}$.

For feeding the SISAB data, two software systems were offered through the e-SUS AB strategy as instruments for data collection: a) Simplified Data Collection (CDS) and; 2) Citizen's Electronic Health Record (PEC). The CDS system was formulated to assist Primary Care teams working in UBS with a low computerization structure, allowing the recording of the summary of professional assistance on paper sheets and/or in the system itself. The software uses different forms to record information, which are organized in three blocks: a) $A B$ registration; b) attendance of higher education professionals and; c) attendance of mid-level professionals ${ }^{(4)}$.

The PEC software system was created for UBS with stable access to the internet and assists the entire flow of the unit, such as, professionals' appointments, attendance list, citizen's medical history, home care, transferring the unit's data and generation of reports, constituting an important technological device to structure the work of the health professionals of the UBS ${ }^{(1,4)}$. According to MS, the PEC system has the potential to improve the care offered to the population, expand the clinical capacity of professionals, optimize expenses on information management and share information among health professionals. This system also performs the systematization of health information registration, integrating instruments to support management processes, and decision making ${ }^{(4)}$.

The process of implementing and using the software systems that make up the e-SUS AB strategy seeks to impact all levels of government management in the country ${ }^{(4)}$. As a proposal, it is central that the e-SUS AB strategy software guarantee a broad and standardized process for the exchange of health information between different levels of care ${ }^{(4)}$.

However, there are some difficulties during the implementation of these systems, such as the insufficiency of funds for the implementation process, the insufficiency of material resources in the municipalities, the poor technology qualification of professionals, low connectivity, even though some of them are expected and moderate ${ }^{(5-6)}$. Also, difficulties that emerge in the context of the implementation of the e-SUS AB strategy: difficulties in editing the data, unsatisfactory reports, difficulties in managing a large number of forms and handling the data, filling errors, unavailability of computers, among others ${ }^{(6)}$.

It is also noteworthy the importance of municipal managers of the e-SUS AB strategy in the implementation of available software systems. This professional and a team are responsible for carrying out the local diagnosis and define the appropriate scenario for the implementation of the systems. Besides, they must qualify and monitor the $A B$ teams in the use of the available instruments.

The process of implementing the software systems of the e-SUS AB strategy is still ongoing and has involved all SUS management bodies and government spheres in the development of a great effort due to the geographic dimensions of the country ${ }^{(4)}$. However, this implementation process needs to be analyzed to get to know its real panorama as well as the barriers and challenges that emerge in this context $\mathrm{t}^{(6-8)}$.

\section{OBJECTIVE}

To analyze factors associated with the implementation of the software systems of the e-SUS Primary Care strategy in municipalities of Minas Gerais.

\section{METHODS}

\section{Ethical aspects}

This study complied with the ethical precepts for research involving human beings of Resolution 466/2012 of the National Health Council and was approved by the Ethics Committee in research with Human Beings. Participants were informed about the objectives, justification, risks, and benefits of the study. The Informed Consent Term was presented electronically, and the acceptance was also registered online.

\section{Design, period and place of study}

This is an observational, quantitative study, with a cross-sectional design that had the municipalities of the State of Minas Gerais as its unit of analysis. The participants in this study were the municipal managers of the e-SUS AB strategy. According to guidelines from the Ministry of Health, each municipality must name at least one professional responsible for the implementation of the strategy, which is called the municipal manager of the e-SUS AB strategy ${ }^{(9)}$. The study was carried out between March 2016 and May 2017.

\section{Population or sample, inclusion criteria}

A random sample was calculated, considering the 853 municipalities and their respective population sizes (IBGE) ${ }^{(10)}$. A significance level and a sampling error of $5 \%$ were used, reaching a total sample of 100 municipalities stratified according to population size. Since it is a web survey and considering a response rate of 
55\%, 182 municipalities were chosen at random. The draw was carried out with the help of the statistical software Statistical Package for the Social Sciences (SPSS) 21.0.

\section{Study protocol}

Data collection took place through the application of a pre-tested online web survey type questionnaire. This type of questionnaire allows gathering a large amount of data in a short time and offers many advantages, not only in terms of costs but also in terms of data quality ${ }^{(11)}$. Participants were previously contacted by phone, receiving the link to the instrument by email, as well as the informed consent form. The invitation email was sent three times in a row of the participants. When there was no return, telephone contact was made again as another attempt for an invitation. In the end, a response was obtained from 114 municipalities, totaling a response rate of $62.6 \%$. The responses of the participants were recorded electronically through the online research website called Online Pesquisa.

The instrument was built based on the strategies defined in the manuals that address the national guidelines for the implementation of the Ministry of Health's e-SUS AB strategy ${ }^{(4)}$. The following related issues were addressed: Profile of the municipal manager of the e-SUS AB strategy; Steps taken to implement the e-SUS AB strategy; Implementation scenarios; Training processes and Computerization of UBS.

\section{Analysis of results and statistics}

The collected data were tabulated and analyzed using the statistical software Statistical Package for the Social Sciences (SPSS) version 21.0. Initially, descriptive analysis procedures were used: absolute and relative frequency and average calculation. Then, bivariate exploratory analyzes were performed using the chi-square test to identify the variables associated with the implementation of the e-SUS AB strategy. The independent variables tested were the population size of the municipality, the profile of the municipal manager of the e-SUS AB strategy (training, time in the position, employment, having received training for the position and perform other duties) and training for professionals in the $A B$ in the municipality.

A multivariate analysis was also carried out through the construction of logistic regression models. In this analysis, variables with $p$-value $<0.20$ were modeled in the bivariate analysis. After the execution of non-automatic reverse procedures, only those with a $5 \%$ significance level remained in the final model. With the modeling, the odds ratio values were also estimated with respective $95 \%$ confidence intervals. The occurrence of multicollinearity was analyzed using the Vif test. The adjustment of the models, in turn, was evaluated through the Hosmer and Lemeshow test and standardized residual plots and standard QQ plot.

\section{RESULTS}

Most of the managers were female (57.9\%), did not have a valid position (52.6\%), and had other positions besides the manager of the e-SUS AB strategy (83.3\%). The average age of the participants was 33 years, and $47.4 \%$ had a college degree. Among the participants with higher education, $46.3 \%$ were graduated in nursing. The average time working in the municipal health departments was 60.3 months, and the average time as a manager of the e-SUS AB strategy was approximately 20 months.

Most municipal managers of the e-SUS AB strategy had training to exercise their role. Training had an average of 15 hours, and most of them (52.6\%) were carried out by the State Health Secretariat through the Regional Health Superintendencies.

The e-SUS AB strategy systems were implemented in $49.1 \%$ (95\% Cl: $39.5-58.8$ ) of the municipalities. In $29.8 \%$, there was the adoption of the CDS system and the PEC system in $19.3 \%$. A smaller proportion of implementation was found in municipalities between ten and twenty thousand inhabitants (37.5\%) (Table 1). Concerning financing, $57.9 \%$ of the municipalities reported that they had not received specific resources for the implementation of the systems.

Table 1 - Implementation of software systems of the e-SUS Primary Care strategy according to the population size of the municipalities, Minas Gerais, Brazil, 2017

\begin{tabular}{|c|c|c|c|}
\hline \multirow{2}{*}{$\begin{array}{l}\text { Population size } \\
\text { (per } 1.000 \text { inhabitants) }\end{array}$} & \multicolumn{3}{|c|}{$\begin{array}{l}\text { Implementation of e-SUS Primary Care } \\
\text { strategy software systems (CDS or PEC) }\end{array}$} \\
\hline & $\begin{array}{l}\text { Yes } \\
n(\%)\end{array}$ & $\begin{array}{l}\text { No } \\
\text { n (\%) }\end{array}$ & $\begin{array}{l}\text { Total } \\
\text { (n) }\end{array}$ \\
\hline Less than 5 & $16(47.1)$ & $18(52.9)$ & 34 \\
\hline From 5 to $<10$ & $16(50.0)$ & $16(50.0)$ & 32 \\
\hline From 10 to $<20$ & $09(37.5)$ & $15(62.5)$ & 24 \\
\hline From 20 to $<50$ & $08(53.3)$ & $07(46.7)$ & 15 \\
\hline From 50 to $<100$ & $02(50.0)$ & $02(50.0)$ & 04 \\
\hline 100 and over & 05 (100) & $0(0)$ & 05 \\
\hline Total & $56(49.1)$ & $58(50.9)$ & 114 \\
\hline
\end{tabular}

Table 2 presents the bivariate analysis of factors that are related to the process of implementing the software systems of the e-SUS AB strategy. It is observed that the manager whose link employment in the municipality comes from a public tender, who has worked in this process for more than a year, having been trained and who proposed to carry out training on the software in his municipality managed to implement this strategy in the cities investigated. The fact that the manager has higher education and performs more than one function in the municipality, regardless of population size, was not associated with the implementation of the systems.

Table 3 shows the variables that remained in the final model, thus being associated with the implementation of the e-SUS $A B$ strategy software systems. Managers who have worked in the position for more than a year and a half had a 3.03 times greater chance than those with less time in the position. The municipalities that carried out training on the systems for their $A B$ professionals had a 2.28 higher chance of implementing any of the systems. 
Table 2 - Characteristics related to the implementation of the software systems of the e-SUS Primary Care Strategy, Minas Gerais, Brazil, 2017

\begin{tabular}{|c|c|c|c|}
\hline \multirow[b]{2}{*}{ Variables } & \multicolumn{2}{|c|}{ Implementation of e-SUS Primary Care strategy } & \multirow[b]{2}{*}{$p$ value } \\
\hline & $\begin{array}{l}\text { Yes } \\
\text { n (\%) }\end{array}$ & $\begin{array}{c}\text { No } \\
\text { n (\%) }\end{array}$ & \\
\hline \multicolumn{4}{|l|}{ Porte Populacional } \\
\hline Up to 20.000 inhabitants & $41(73.2)$ & $49(84.5)$ & 0.140 \\
\hline Over 20.000 inhabitants & $15(26.8)$ & $9(15.5)$ & \\
\hline \multicolumn{4}{|l|}{ Higher education } \\
\hline Yes & $30(53.6)$ & $24(41.4)$ & 0.192 \\
\hline No & $26(46.4)$ & $34(58.6)$ & \\
\hline \multicolumn{4}{|l|}{ Graduate school } \\
\hline Yes & $18(32.1)$ & $11(19.0)$ & 0.106 \\
\hline No & $38(67.9)$ & $47(81.0)$ & \\
\hline \multicolumn{4}{|c|}{ Time working as an e-SUS Primary Care strategy manager } \\
\hline Up to 1 year and a half & $24(42.8)$ & $36(62.1)$ & 0.040 \\
\hline Over 1 year and a half & $32(57.2)$ & $22(37.9)$ & \\
\hline \multicolumn{4}{|c|}{ Performs other positions besides e-SUS Primary Care strategy manager } \\
\hline Yes & $50(89.3)$ & 45 (77.6) & 0.094 \\
\hline No & $6(10.7)$ & $13(22.4)$ & \\
\hline \multicolumn{4}{|l|}{ Public Servant } \\
\hline Yes & $32(57.1)$ & $22(37.9)$ & 0.040 \\
\hline No & $24(42.9)$ & $36(62.1)$ & \\
\hline \multicolumn{4}{|c|}{ Had training on e-SUS Primary Care strategy softwares } \\
\hline Yes & $45(80.4)$ & $37(63.8)$ & 0.049 \\
\hline No & $11(19.6)$ & $21(36.2)$ & \\
\hline \multicolumn{4}{|c|}{ Had training for Primary Care professionals in the municipality } \\
\hline Yes & $34(60.7)$ & $20(34.5)$ & 0.005 \\
\hline No & $22(39.3)$ & $38(65.5)$ & \\
\hline
\end{tabular}

Table 3 - Multivariate analysis of the implementation of e-SUS Primary Care strategy systems, Minas Gerais, Brazil, 2017

\begin{tabular}{lccc}
\hline Variables & $\begin{array}{c}\boldsymbol{p} \\
\text { value }\end{array}$ & $\begin{array}{c}\text { Odds } \\
\text { Ratio }\end{array}$ & $\mathbf{C l 9 5 \%}$ \\
\hline $\begin{array}{l}\text { Time working as an e-SUS Primary Care } \\
\text { strategy manager } \\
\quad \text { Up to 1 year and a half }\end{array}$ & & & \\
$\quad$ Over 1 year and a half & 0.005 & 3.03 & $1.39-6.62$ \\
Had training in the municipality & & & \\
$\quad$ No & & 1 & \\
$\quad$ Yes & 0.039 & 2.28 & $1.04-4.97$ \\
\hline Note: Cl-Confidence interval. & & & \\
$\quad$ DISCUSSION & & &
\end{tabular}

Using information technologies in the context of Primary Care, in a continental country like Brazil, is a complex process and of such magnitude. This requires high investment by those involved, especially the managers responsible for implementing such technology ${ }^{(5-7)}$. This finding was also confirmed in this study, where it was found that the presence of a trained manager at the front of the implementation process impacts the implementation of the e-SUS AB strategy software systems in the cities studied.

The national guidelines for the implementation of the e-SUS AB strategy would already determine to indicate, by the municipalities, professionals qualified to coordinate the implementation of this strategy ${ }^{(9)}$. This professional, called the manager, would have the responsibility to develop and direct the implementation process to achieve its success ${ }^{(9)}$. However, in this same guideline, there are no requirements or criteria for defining the choice of this professional, as well as the job assignments are not specified ${ }^{(12-13)}$. Thus, it is necessary to define the duties and skills of this professional, qualifying this choice. It is known that the achievement of the implementation of information technologies in the health context depends on the involvement of managers and professionals, as well as their qualification, envisioning qualified managerial and clinical decision-making ${ }^{(5,7,12-15)}$.

Another finding in this study concerns the fact that the training processes proposed to health professionals by the managers of the e-SUS AB strategy contributed to the implementation of software systems. It is increasingly important to carry out systematic and continuous training processes in the implementation of information technologies, as their absence can make implementation impossible, in addition to encouraging little use of it ${ }^{(14-15)}$.

The cases of unsuccessful implementation of health information technologies can often be attributed to the lack of technical training, in addition to the gaps between the scenario projected during the conception of the technology and the reality in which it is implemented ${ }^{(16)}$. Besides, the incipient educational processes is the result of the absence of a professional qualification policy, contributing to low rates of implementation and use of technologies in their entirety ${ }^{(17)}$.

Even considering the different possible scenarios for implementing the e-SUS AB strategy, in municipalities of different population sizes, this strategy has not been successful in its implementation. Half of the municipalities studied did not implement any software system (CDS or PEC). It is also important to mention that the use of the PEC system was often not the first choice. This becomes another challenge for the implementation of the e-SUS AB strategy since the MS has defined that all Brazilian UBS should adopt this system ${ }^{(2)}$. For this to happen, all UBS must have access to a stable internet connection, which, by the results, is still far from being a reality. Quality connectivity still presents itself as an important obstacle in Brazil, due to the high costs of its acquisition and maintenance, as well as aspects related to the infeasibility of the network and unavailability of computers ${ }^{(18-21)}$. 
Also, in rural areas, internet access is difficult, and the connection speed is lower than necessary, situations that are still typical in the Brazilian scenario ${ }^{(20)}$.

Thus, for the successful implementation of the e-SUS AB strategy, advances are still needed, which include the need to legitimize, recognize and apply the National Health Information and Informatics Policy (PNIIS) in these practice scenarios $^{(20,22)}$. Even the e-Health strategy for Brazil, already assigned, still lacks applicability in the health service network in the country ${ }^{(23)}$. In this sense, we have a public policy for the area of health information and information technology, a strategy with an e-health model, regulations, and guidelines for the implementation of the e-SUS AB strategy. This shows government awareness about the need for a qualified computerization process. However, the process of implementing information technologies is still carried out in a precarious, unsystematic manner, with low funding, in addition to the lack of infrastructure already typical of most public health services in $\operatorname{Brazil}^{(18,20,22,24-25)}$. Such situations became challenges for managers that, despite being possible mobilizers of the computerization process, as demonstrated in the results of this study, the need to overcome these difficulties is notorious.

In addition, the e-SUS AB strategy is configured as an innovation, its operationalization still involves adjustments and software updates. Its implementation process occurs gradually, which limits the managers' experiences related to its efficiency and effectiveness ${ }^{(18,25)}$.

\section{Study limitations}

One of the limitations of this study is assigned to the possibility of overestimating the implementation of the software systems of the e-SUS AB strategy, since the data were selfreported by the responsible managers. Another aspect refers to the time frame for data collection regarding the procedural characteristic of the implementation of information technologies. Thus, the results found and discussed illustrate a certain period of computerization, and should evolve to other levels over time, referring to the need for continued monitoring of the computerization process.

\section{Contributions to the health area}

This study proves to be relevant for the health area, especially for Primary Care, a field of great nursing performance, since it identifies the stage of implementation of the software systems linked to the e-SUS AB strategy. It is essential to highlight that in the literature, there are many records of failure in the adoption and implementation of new information technologies, mainly in the context of Brazilian public health. Therefore, the knowledge of the implementation stage of the analyzed software systems, and the identification of the factors associated with the success of the implementation, can significantly contribute to the improvement and empowerment of the institutions, thus reducing failure possibilities.

The study also has the potential to contribute to improving the knowledge of health professionals about the strategies used by the federal government in the computerization of UBS. We emphasize that the e-SUS AB strategy seeks to organize and systematize information, qualifying the work, management, and coordination of care ${ }^{(3-4)}$. This requires changes in the mindset and practices of professionals and users of the service ${ }^{(3)}$.

\section{CONCLUSIONS}

We identified that the implementation of the e-SUS AB strategy is still evolving, and the presence of the manager as a mobilizer of such a process is the main factor associated with the advances achieved so far in the cities evaluated. We believe that making feasible strategies aimed at this manager, allowing more exclusively dedication to AB's computerization actions, may enhance this process, even with the technological, operational, and infrastructure limitations verified in these municipalities. The training of health professionals present in the UBS also conformed as another factor associated with the implementation of the e-SUS AB strategy software systems, referring to the need for its continuity.

Finally, reassessment processes and discussions about the advances to date would contribute to enhance the results of new stages, as well as the guarantee of financial support, opening for discussion and exchange of experiences, raising awareness about the importance of using information in the process of municipal assessment and decision-making.

\section{REFERENCES}

1. Ministério da Saúde (BR). Portaria no 1.415, de 10 de julho de 2013. Institui o Sistema de Informação para a Atenção Básica (SISAB) [Internet]. Brasília: Ministério da Saúde; 2013 [cited 2018 out 11]. Available from: bvsms.saude.gov.br/bvs/saudelegis/gm/2013/prt1412_10_07_2013. html

2. Ministério da Saúde (BR). Portaria n 2.983, de 11 de novembro de 2019. Institui o Programa de Apoio à Informatização e Qualificação dos Dados da Atenção Primária à Saúde - Informatiza APS [Internet]. Brasília: Ministério da Saúde; 2019 [cited 2019 Nov 30]. Available from: https://www.in.gov.br/en/web/dou/-/portaria-n-2.983-de-11-de-novembro-de-2019-227652196

3. Ministério da Saúde (BR). CONASS. Nota Técnica 07/2013. Estratégia e-Sus Atenção Básica. Sistema de Informação em Saúde da Atenção Básica - SISAB [Internet]. 2013. [cited 2018 Oct 10]. Available from: www.conass.org.br/biblioteca/wp-content/uploads/2013/01/NT-072013-e-SUS-e-SISAB.pdf.

4. Ministério da Saúde (BR). Secretaria de Atenção à Saúde. Departamento de Atenção Básica. e-SUS Atenção Básica: manual de implantação [Internet]. Brasília: Ministério da Saúde; 2014 [cited 2018 Oct 13]. 63 p. Available from: 189.28.128.100/dab/docs/portaldab/documentos/ manual_implantacao_esus.pdf 
Computerization of primary health care: the manager as a change agent

5. Silva TIM, Cavalcante RB, Santos RC, Gontijo TL, Guimarães EAA, Oliveira VC. Difusão da inovação e-SUS Atenção Básica em equipes de saúde da família. Rev Bras Enferm. 2018;71(16)2945-52. doi: 10.1590/0034-7167-2018-0053

6. Oliveira AEC, Lima IMB, Nascimento JA, Coelho HFC, Santos SR. Implantação do e-SUS AB no Distrito Sanitário IV de João Pessoa (PB): relato de experiência. Saúde Debate. 2016;40(109):212-8. doi 10.1590/0103-1104201610917

7. Cavalcante RB, Silva HRM, Santos RC, Silva TIM, Guimarães EAA, Pinheiro MMK. Diffusion of the technological innovation e-sus AB: acceptance or rejection. Cogitare Enferm. 2018;23(3):e55911. doi: 10.5380/ce.v23i3.55911

8. Astolfo S, Kehrig RT. O processo de implantação de uma estratégia integrada de SIS na APS no Mato Grosso, Brasil. Rev Saúde Col UFES. 2017;7(1):8-15. doi: 10.13102/rscdauefs.v7i1.1169

9. Ministério da Saúde (BR). Secretaria Executiva. Departamento de Monitoramento e Avaliação do SUS. Política Nacional de Informação e Informática em Saúde [Internet]. 2016 [cited 2018 Oct 13]. 56 p. Available from: http://bvsms.saude.gov.br/bvs/publicacoes/politica_ nacional_infor_informatica_saude_2016.pdf

10. Instituto Brasileiro de Geografia e Estatística (IBGE). Censo demográfico [Internet]. 2017[cited 2018 Oct 13]. Available from: www.ibge.gov. br/home/estatistica/populacao/censo2010/default.shtm.

11. Foina A. Métodos de aquisição de dados quantitativos na internet: o uso da rede como fonte de dados empíricos. Cienc Tróp [Internet]. 2002 [cited 2018 Oct 19];30(2):283-96. Available from: fundaj.emnuvens.com.br/CIC/article/viewFile/778/509

12. Ovies-bernal DP, Agudelo-londoño SM. Lecciones aprendidas em la implementación de sistemas nacionales de información de salud interoperables: una revisión sistemática. Rev Panam Salud Publica [Internet]. 2014 [cited 2018 Nov 19];35(5):415-23. Available from: www. scielosp.org/pdf/rpsp/2014.v35n5-6/415-423/es

13. Seitio-kgokgwe O, Gauld RDC, Hill PC, Barnett P. Development of the National Health Information Systems in Botswana: pitfalls, prospects and lessons. Online J Public Health Inform. 2015;7(2):e210. doi: 10.5210/ojphi.v7i2.5630

14. Duarte MLC, Tedesco JR, Parcianello RR. O uso do sistema de informação na Estratégia Saúde da Família: percepção dos enfermeiros. Rev Gaúcha Enferm [Internet]. 2012 [cited 2019 Jan 22];33(4):111-7. Available from: seer.ufrgs.br/RevistaGauchadeEnfermagem/article/ view/26439/23960

15. Cavalcante RB, Bernardes MFVG, Gontijo TL, Guimarães EAA, Oliveira VC. Sistema de informação da atenção básica: potencialidades e subutilização no processo decisório. Cogitare Enferm. 2013;18(3):460-7. doi: 10.5380/ce.v18i3.33555

16. Pinheiro ALS, Martins AFP, Pinto IC, Silva DO, Zacharias FCM, Gomide MFS. The use of information systems: challenges for health management. Ciênc Cuid Saude. 2015;14(3):1307-14. doi: 10.4025/cienccuidsaude.v14i3.24356

17. Fornazin M, Joia LA. Remontando a rede de atores na implantação de um sistema de informação em saúde. Rev Adm Empres. 2015;55(5):527-38. doi: 10.1590/S0034-759020150505

18. Carvalho MF, Santos IJR, Boery EM, Setenta CA. Análise estrutural da informatização da atenção básica no estado da Bahia, Brasil. J Manag Prim Heal Care. 2015;6(2):178-88. doi: 10.14295/jmphc.v6i2.265

19. Woodward A, Fyfe M, Handuleh J, Pate P, Godman B, Leather A, et al. Diffusion of e-health innovations in 'post-conflict' settings: a qualitative study on the personal experiences of health workers. Hum Resour Health. 2014;12(22):2-10. doi: 10.1186/1478-4491-12-22

20. Associação Brasileira de Pós-Graduação em Saúde Coletiva-Abrasco. Grupo Técnico de Informação em Saúde e População-GTISP. Plano Diretor para o desenvolvimento da Informação e Tecnologia de Informação em Saúde - PlaDITIS 2013-2017: no contexto da atual governança de informação e de implantação do Registro Eletrônico em Saúde/RES[Internet]. Brasília: ABRASCO; 2013 [cited 2017 Apr 01]. Available from: http://www.abrasco.org.br/site/wp-content/uploads/2015/06/GT_informacao_plano-diretor.pdf

21. Oliveira F, Goloni-Bertollo EM, Pavario EC. The Internet as a source of health information. J Health Inform[Internet]. 2013 [cited 2015 Jul 14];5(3):98-102. Available from: http://www.jhi-sbis.saude.ws/ojs-jhi/index.php/jhi-sbis/article/view/267.pdf

22. Cavalcante RB, Kerr-Pinheiro MM, Guimarães EAA, Miranda RM. Panorama de definição e implementação da Política Nacional de Informação e Informática em Saúde. Cad Saúde Pública. 2015;31(5):960-70. doi: 10.1590/0102-311X00095014

23. Ministério da Saúde (BR). Comitê Gestor da Estratégia e-Saúde. Estratégia e-saúde para o Brasil [Internet]. Brasília: Ministério da Saúde; 2017 [cited 2019 Dec 5]. 80 p. Available from: https://www.conasems.org.br/wp-content/uploads/2019/02/Estrategia-e-saude-para-o-Brasil.pdf

24. Santos AF, Sobrinho DF, Araújo LL, Procópio CSD, Lopes EAS, Lima AMLD, et al. Incorporação de tecnologias de informação e comunicação e qualidade na atenção básica em saúde no Brasil. Cad Saúde Pública. 2017;33(5):1-14. [cited 2019 Nov 28]. Available from: https://www. scielo.br/pdf/csp/v33n5/1678-4464-csp-33-05-e00172815.pdf

25. Cavalcante RB, Esteves CJS, Gontijo, TL, Brito MJM, Guimarães EAA. Rede de atores e suas influências na informatização da Atenção Básica à Saúde no Brasil. Interface. 2019;23:e180364 doi: 10.1590/Interface.180364 